\title{
OVER-WINTER STORAGE OF CONIFEROUS SEEDLINGS AS A MEANS OF PREVENTING LATE FROST DAMAGE ${ }^{1}$
}

\author{
BY E. JORGENSEN ${ }^{2}$ and W. K. L. STANEK ${ }^{3}$
}

W. K. L. Stanek was born in Bruenn, Czechoslovakia, in 1926; he obtained his B.Sc.F. at the University of Munich, Germany, in 1955; and his M.Sc.F. at the University of Toronto in 1961. He gained practical experience in forestry in Finland and Sweden and in 1955-56 was Scientific Assistant with the University of Munich in forest tree breeding. He has been Research Forester in the Northern Region of Ontario since 1957 when he joined the Research Branch, Ontario Department of Lands and Forests.

\section{ABSTRACT}

In a series of experiments on over-winter storage, seedlings of white spruce and other conifers were placed in normal shipping bales and stored in root cellars without artificial refrigeration. White spruce seedlings were retained in dormant condition for approximately six months without apparent damage to their later performance in plantations. Stored seedlings proved highly resistant to damage from spring frosts and therefore superior to spring-shipped stock from the same nursery beds. Conclusive evidence of the suitability of other conifers for over-winter storage was not obtained. The application of overwinter storage of white spruce seedlings in planting operations in northern Ontario is discussed.

\section{INTRODUCTION}

The Ontario Department of Lands and Forests is engaged in a planting program in northern Ontario which, until seedlings can be supplied in adequate numbers by nurseries established in that part of the Province, utilizes seedlings supplied by the large provincial nurseries located at Kemptville, Midhurst, Orono, or St. Williams in southern Ontario. Technical difficulties in the establishment of special camps, in the transportation of seedlings over long distances by truck, train, or aircraft, and in the supervision of planting and tending of the plantations, have been encountered in this program. Biological difficulties, too, have under certain circumstances resulted in complete failure of some planting projects.

In 1956 and 1957, the Forest Pathology Laboratory at Maple received requests from northern forest districts for diagnosis of diseases in young coniferous plantations. In response to these requests the senior author conducted an investigation which led to the conclusion that spring frost, rather than the action of fungi or insects, was the primary cause of damage in

\footnotetext{
${ }^{1}$ Contribution No. 806 from the Entomology and Pathology Branch, Department of Forestry, Ottawa, Canada, and Contribution No. 61-2 from the Ontario Department of Lands and Forests, Research Branch, Maple, Ont.

"Formerly Forest Pathology Laboratory, Maple, Ont.; now Assistant Professor (Forest Pathology), Faculty of Forestry, University of Toronto, Toronto, Ont. Biographical reference in For. Chron. 32:87. 1956.

${ }^{a}$ Research Branch, Ontario Department of Lands and Forests, Cochranc, Ont.
} 
these stands. As a result of these field observations, the experiments described herein were begun in the fall of 1957 (3). The purpose of the experiments was to examine the possibilities of over-winter storage close to northern planting sites as a means of preventing spring frost damage.

\section{Procedures at the Nursery and Ship ping of Stock}

For each experiment, selections of seedling material for storage and for spring shipping was made from the same beds at the nursery. Black spruce (Picea mariana (Mill.) B.S.P.) was delivered from the Provincial Forest Tree Nursery at Kemptville, Ontario, while white spruce (Picea glauca (Moench) Voss), white pine (Pinus strobus L.), red pine (Pinus resinosa Ait.), and jack pine (Pinus banksiana Lamb.) were grown at the Provincial Forest Tree Nursery at St. Williams, Ontario. Shipping bales were used for transportation and storage of seedlings. The seedlings were tied into bundles of 50, which were placed root to root, with sphagnum moss around the root system, and wrapped in wax paper and burlap to a normal sized bale.

The fall-shipped stock, which arrived by rail at Cochrane, was immediately placed in a root cellar (Figs. 1 and 2).

In the spring of 1958 , seedlings for experimental planting were shipped, together with the regular stock, for planting in the forest district at approximately the middle of the period of shipping from the nursery. When the shipped seedlings arrived at Cochrane, stored seedlings were removed from storage and handled in the same way as shipped seedlings until preparation of the planting site had been completed.

To weight the conditions in favour of spring shipment the experimental stock was in 1959 shipped at the earliest opportunity, and arrived in Cochrane three weeks ahead of the regular planting stock for the district. The stored seedlings were not in this year removed from storage until after the springshipped seedlings were planted.

\section{Facilities and Conditions of Storage}

To facilitate storage two root cellars were built, one in 1957 and one in 1958 , on the west side of an esker close to the Nellie Lake ranger cabin, 25 miles south of Cochrane, Ontario.

For each cellar an excavation approximately 4.5 feet deep was made in the shade of a jack pine stand. Within this excavation the root cellars were constructed as shown in Fig. 3. The door faced east because of the believed favorable exposure. Adjustable ventilation was provided through two wooden ducts $\left(9^{\prime \prime} \times 9^{\prime \prime}\right)$ leading to the floor of the shelter from 6 feet above the ground. Ducts were provided with caps to prevent snow from entering. Two wire-mesh vents were provided in the door. The roof and outside walls were insulated with tar paper to exclude moisture. Except for the eastern entrance the building was covered with gravel and finally with a 1-foot layer of sand (Fig. 1). Racks, constructed of 2" $\times 4^{\prime \prime}$ lumber, were installed along the inside walls to support the stored bales and allow for their aeration (Fig. 2).

The dates of commencement and termination of storage, as well as a description of the general appearance of the seedlings on arrival at Cochrane, are given in Table 1. 
TABLE 1

Cold-STORAGE $1957-1958-1959$

\begin{tabular}{|c|c|c|c|c|c|c|c|c|}
\hline \multirow{2}{*}{$\begin{array}{l}\text { No. of } \\
\text { bales }\end{array}$} & \multirow[b]{2}{*}{ Species } & \multirow[b]{2}{*}{ Age } & \multirow{2}{*}{$\begin{array}{l}\text { No. of } \\
\text { seed- } \\
\text { lings }\end{array}$} & \multirow{2}{*}{$\begin{array}{l}\text { Stored } \\
\text { in } \\
\text { Shelter } \\
\text { No. }\end{array}$} & \multirow{2}{*}{$\begin{array}{l}\text { Arrival in } \\
\text { Cochrane and } \\
\text { beginning } \\
\text { of storage }\end{array}$} & \multirow{2}{*}{$\begin{array}{l}\text { End of } \\
\text { storage }\end{array}$} & \multicolumn{2}{|c|}{ Condition of stock } \\
\hline & & & & & & & Before storage & Before planting \\
\hline & & & & & \multicolumn{2}{|c|}{ Fall-shipped 1957} & & \\
\hline 2 & Sw & $2 / 2$ & 1200 & 1 & Nov. 20 & May 2 & nutrient deficiency & (dormant, pale green and \\
\hline 2 & Sw & $3 / 0$ & 3000 & 1 & Nov. 20 & May 2 & nutrient deficiency & (chlorotic, dry appearance \\
\hline & & & & & \multicolumn{2}{|c|}{ Spring-shipped 1958} & & \\
\hline 2 & Sw & $2 / 2$ & 1200 & & May 2 & & & fresh green partly open buds \\
\hline 2 & Sw & $3 / 0$ & 3000 & & May 2 & & & fresh green partly open buds \\
\hline & & & & & \multicolumn{2}{|c|}{ Fall-shipped 1958} & & \\
\hline 2 & Sw & $2 / 2$ & 1000 & 1 & Nov. 28 & May 13 & normal & normal or pale green color \\
\hline 32 & Sw & $2 / 2$ & 16000 & 1 & Nov. 28 & May $15-$ & normal & normal or pale green color \\
\hline 2 & $\mathrm{Sw}$ & $2 / 2$ & 1000 & 1 & Nov. 28 & 20 & normal & normal or pale green color \\
\hline 2 & Sw & $3 / 0$ & 2500 & 2 & Nov. 28 & May 13 & normal & normal or pale green color \\
\hline 2 & $\operatorname{Pr}$ & $2 / 2$ & 1000 & 2 & Nov. 28 & May 12 & normal & normal or pale green color \\
\hline 2 & Pw & $2 / 2$ & 1000 & 2 & Nov. 28 & May 12 & normal & normal or pale green color \\
\hline 2 & $P_{j}$ & $2 / 1$ & 2000 & 2 & Nov. 28 & May 12 & $50 \%$ needles purple & purple more intensive \\
\hline 2 & $\mathrm{Sb}$ & $2 / 2$ & 1000 & 2 & Nov. 19 & May 8 & needles falling off & progress of terminal balding \\
\hline & & & & & \multicolumn{2}{|c|}{ Spring-shipped 1959} & & \\
\hline 2 & Sw & $2 / 2$ & 1000 & & \multicolumn{2}{|c|}{ Apr. 20} & & (normal fresh green with \\
\hline 2 & Sw & $3 / 0$ & 2500 & & \multicolumn{2}{|l|}{ Apr. 20} & & (no swollen buds \\
\hline 2 & $\mathrm{Pr}$ & $2 / 2$ & 1000 & & \multicolumn{2}{|l|}{ Apr. 20} & & (normal fresh green, partly \\
\hline 2 & Pw & $2 / 2$ & 2000 & & \multicolumn{2}{|l|}{ Apr. 20} & & (swollen buds \\
\hline 2 & $P_{j}$ & $2 / 1$ & 2000 & & \multicolumn{2}{|l|}{ Apr. 20} & & (purple needles, swollen buds \\
\hline 2 & $\mathrm{Sb}$ & $2 / 2$ & 2000 & & \multicolumn{2}{|l|}{ Apr. 25} & & (terminals balding \\
\hline
\end{tabular}

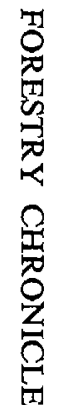

$\mathrm{W}-$ white spruce, $\mathrm{Sb}-$ black spruce, $\mathrm{Pr}-$ red pine, $\mathrm{Pw}$-white pine, $\mathrm{P}$ - jack pine. 


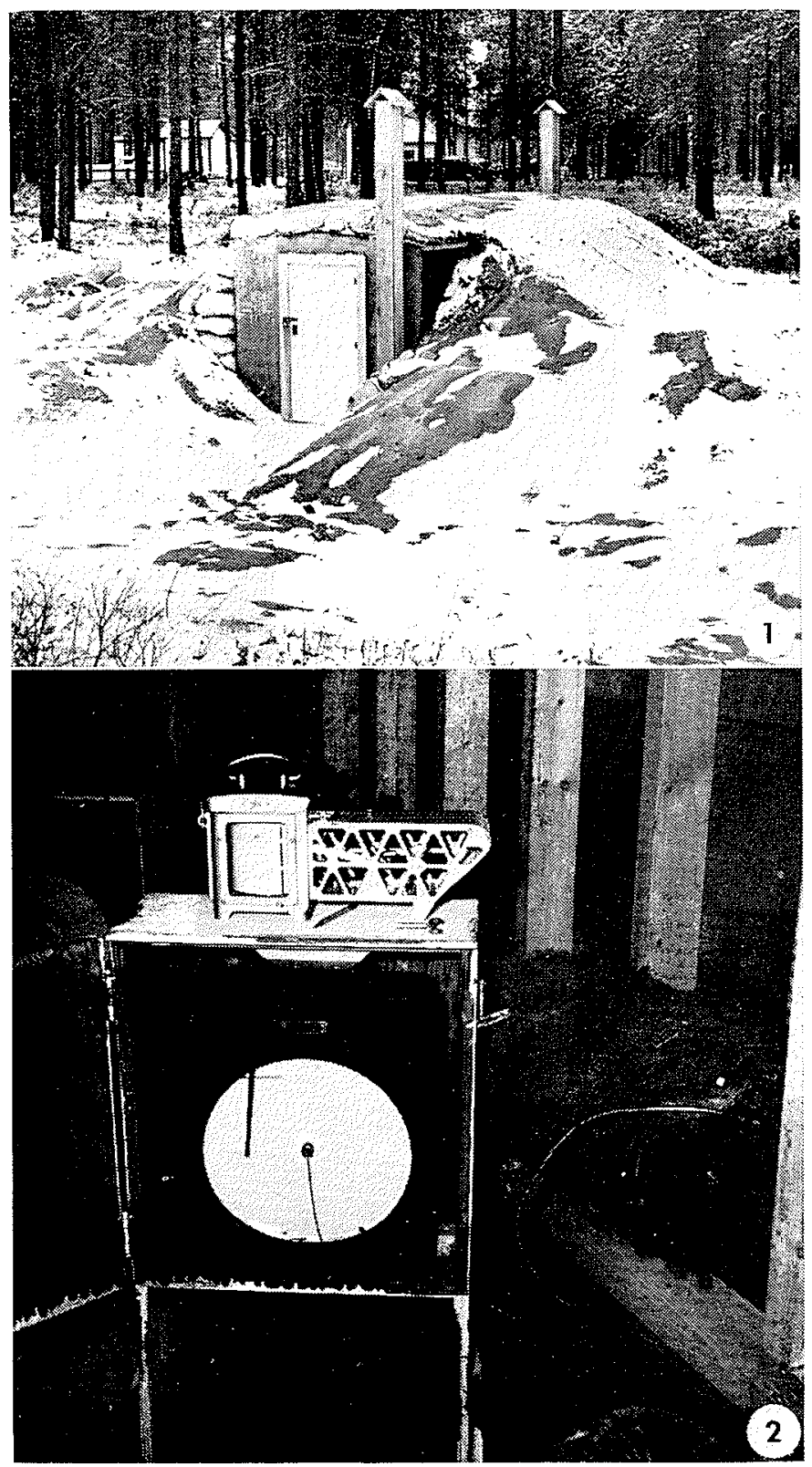

FIGURE 1. Root-cellar at Nellic Lake, Ontario. Photographed May 1, 1958.

FIGURE 2. Interior of root-cellar at Nellic Lake, Ontario. Note thermographs and balc of 2/2 stock on rack. Photagraphed May I, 1958. 
Fig. 3 ROOT-CELLAR AT NELLIE LAKE, ONT.
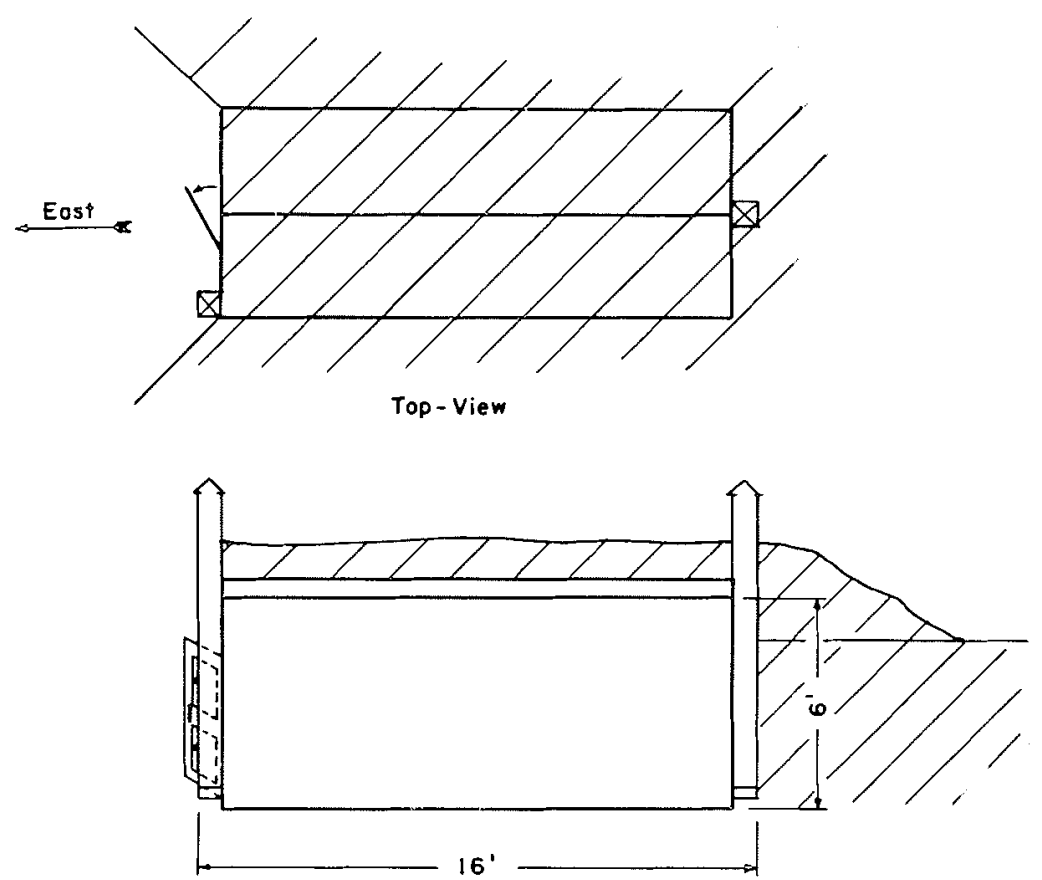

Side - View

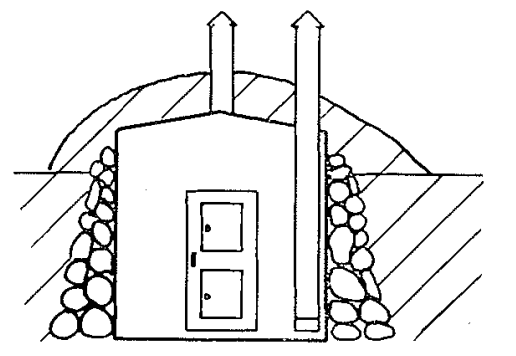

Front-View
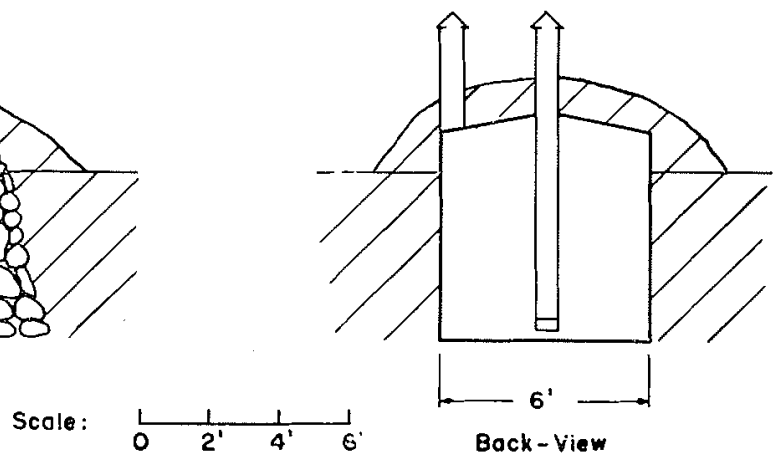

FIGURI: 4. 2/2 white spruce seedlings after one growing season at Cochranc. The two seedlings on the left were spring-shipped. The secdling on the right was storcd. Note the difference in shoot development. Photographed September 2, 1958.

FIGURE: 5, 3/0 white spruce seedlings after one growing season at Cochrane. The two secdlings on the left were spring-shipped. The seedling on the right was stored. Note the difference in shoot development. Photographed September 2, 1958. 
JUNE, 1962
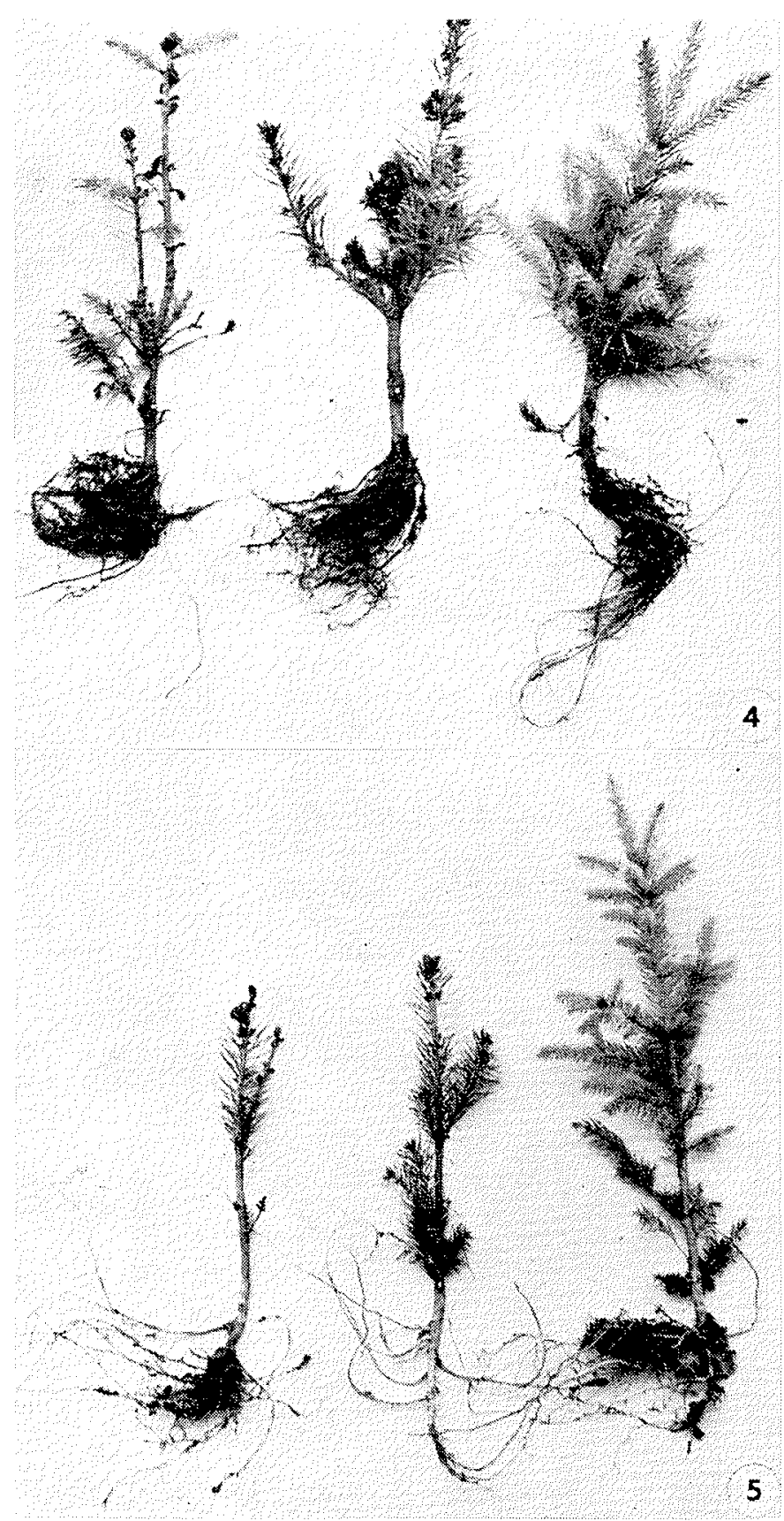
The root temperatures in bales of white spruce stock were recorded on two automatic thermographs (Fig. 2). Maximum and minimum air temperatures in the root cellars were obtained each week from the average of two maximum minimum thermometers.

The general trend in the fluctuation of the air temperature in the root cellars followed the general trend of outside air temperature, but did not reach the same extremes. Although, during the winter of 1957-58, the outside air temperature fell below minus $30^{\circ} \mathrm{F}$, temperatures within the shelter were never lower than $12^{\circ} \mathrm{F}$. In 1958-59, outside temperatures dropped to minus $40^{\circ} \mathrm{F}$ and the inside air temperature was, for a short period only, $2^{\circ} \mathrm{F}$. When in the spring outside air temperatures exceeded $60^{\circ} \mathrm{F}$, the maximum air temperatures in the sheiter remained below $40^{\circ} \mathrm{F}$.

The root temperature showed even a smaller amplitude than the air temperature in the shelter and did not fall below $12^{\circ} \mathrm{F}$ nor exceed $34^{\circ} \mathrm{F}$ during storage.

The relative humidity of the air in the shelters, as measured on recording hygrothermographs, varied between 90 and 95 per cent during the entire storage period.

\section{Planting}

The planting was carried out on abandoned pasture and burned or cutover land using the slit method.

Two similar Latin square designs using white spruce were established in Fournier Township, one in 1958 and one in 1959 on well drained abandoned pasture land. Each design. consisted of 32 plots. Individual plots contained 10 rows of 10 seedlings in a $6 \mathrm{ft} . \times 6 \mathrm{ft}$. spacing.

Also in 1959, in Leitch Township, 32 bales of white and two bales of black spruce stored stock were used for a normal planting operation at an approximate spacing of $6 \mathrm{ft}$. $x 6 \mathrm{ft}$. To make comparisons possible, 15 plots of white and four of black spruce measuring $100 \times 100 \mathrm{ft}$, were established within an area which was planted with spring-shipped white and black spruce.

The pine species were planted in a Latin square design with four replicaltions. The design consisted of 24 plots with 100 seedlings each at 6 -ft. spacing, and was located in Kettle Lakes Park, German Township, on a burned-over jack pine site.

The condition of the planting stock at the time of planting is presented in Table 1. The poor condition of the black spruce seedlings should be noted as well as the difference in bud condition between stored and spring-shipped stock.

In 1958, a few inches of snow fell during and immediately after planting. From May 2 to May 10, and again on May 23 and May 26, night frosts with temperatures as low as $20^{\circ} \mathrm{F}$ were recorded at Cochrane. The days were fairly warm except for May 8 and 9 , when the maximum temperatures were $32^{\circ} \mathrm{F}$ and $36^{\circ} \mathrm{F}$.

In 1959 , the weather during the planting operation was milder than in

\footnotetext{
- Monthly compilations of air temperatures at the Iroquois Falls weather station were obtained through the courtesy of the Department of Transport, Toronto, Ont.
} 
1958 and only light night frosts occurred. There were occasional showers and a snowfall on May 15 . The weather during the following 8 weeks was mild without night frost and with little precipitation.

\section{White Spruce}

\section{EXPERIMENTAL RESUlts}

The results obtained in plantings of stored and unstored white spruce are presented in Table 2

TABLE 2

Results of White Spruce Plantings at the End of One Growing Season

\begin{tabular}{|c|c|c|c|c|c|c|c|c|}
\hline \multirow{3}{*}{$\begin{array}{c}\text { Planting } \\
\text { year } \\
\text { and } \\
\text { place }\end{array}$} & \multirow{3}{*}{$\begin{array}{c}\text { Age and } \\
\text { type of } \\
\text { stock }\end{array}$} & \multirow{3}{*}{$\begin{array}{l}\text { Number of } \\
\text { seedlings } \\
\text { in } \\
\text { experiment }\end{array}$} & \multirow[b]{3}{*}{ Live } & \multicolumn{4}{|c|}{ Percentages } & \\
\hline & & & & & & \multicolumn{3}{|c|}{ Growth of Iive seedlings } \\
\hline & & & & Dead & Missing & NormaI & None & $\begin{array}{c}\text { No } \\
\text { terminal }\end{array}$ \\
\hline Spring & $3 / 0 \mathrm{~S}$ & 800 & 97.0 & 2.0 & 1.0 & 83.0 & 2.0 & 15.0 \\
\hline 1958 & $3 / 0 \mathrm{U}$ & 800 & 98.0 & 2.0 & 0.0 & 25.0 & 23.0 & 52.0 \\
\hline Fournier Twp. & $2 / 2 \mathrm{~S}$ & 800 & 98.0 & 1.0 & 1.0 & 88.0 & 0.0 & 12.0 \\
\hline Conc. IV, Lot 5 & $2 / 2 \mathrm{U}$ & 800 & 96.0 & 3.0 & 1.0 & 7.0 & 13.0 & 80.0 \\
\hline Spring 1959 & $3 / 0 \mathrm{~S}$ & 800 & 74.8 & 24.5 & 0.7 & 78.8 & - & $\overline{21.2}$ \\
\hline Fournier Twp. & $3 / 0 \mathrm{U}$ & 800 & 85.7 & 14.0 & 0.3 & 72.0 & - & 28.0 \\
\hline \multirow[t]{2}{*}{ Conc. II, Lot 2} & $2 / 2 \mathrm{~S}$ & 800 & 94.8 & 5.1 & 0.1 & 88.7 & - & 11.3 \\
\hline & $2 / 2 \mathrm{U}$ & 800 & 96.5 & 3.3 & 0.2 & 75.4 & - & 24.6 \\
\hline $\begin{array}{l}\text { Spring } 1959 \\
\text { Leitch Twp. }\end{array}$ & $2 / 2 \mathrm{~S}$ & 3600 & 99.4 & 0.6 & - & 87.4 & - & 12.6 \\
\hline $\begin{array}{l}\text { Conc. VI and } \\
\text { VII, Lots } 9-13\end{array}$ & $2 / 2 \mathrm{U}$ & 3600 & 98.0 & 2.0 & 一 & 63.5 & - & 36.5 \\
\hline
\end{tabular}

Types: S-stored, U-unstored.

The 1958 planting revealed a considerable difference in performance between spring-shipped and stored stock, although the survival was very satisfactory in both types of stock. Figs. 4 and 5 illustrate this difference in performance. The damage was typical of that described by Day (2) and Neger (5) as due to spring frost injury.

Two years after planting, some of the spring-shipped seedlings showed no shoot development at all, having stagnated at the stage in which they were planted. A major part of the unstored seedlings showed some new shoots, but no terminal growth development. Only a small number of the seedlings developed normal terminals. Stored stock was in a good condition and formed satisfactory plantings.

In the 1959 plantings in Fournier Township, the survival of unstored seedlings was slightly better than for stored stock, and the difference in performance between the two types of stock was less than in the 1958 planting, although in favor of stored stock.

In Leitch Township, where stored $2 / 2$ white spruce from St. Williams was compared to spring-shipped stock of unknown origin, the difference in seedling performance was clearly in favor of the stored stock and similar to that observed in the 1958 experiment. 
Statistical analysis confirmed that the number of trees with dead terminals had been decreased very significantly through storage in both years.

In the 1958 experiment there was very little difference in mortality of the two classes of stock, while the 1959 experiment showed, at the 5 per cent level, a significantly higher mortality of the $3 / 0$ class than of the $2 / 2$ class. Also in the 1959 experiment, the stored stock with an average of 15 per cent mortality compared to an average of 9 per cent mortality of unstored stock, proved significantly poorer than the unstored stock in this respect, at the 5 per cent level.

The variance between stock from different nursery beds was shown to be insignificant in the 1959 experiment. This factor was not investigated in 1958.

\section{Black Spruce}

Planting of black spruce in Leitch Township in 1959 resulted in 80 per cent survival of stored stock with 20 per cent killed terminal shoots, compared to 84.6 per cent survival of spring-shipped stock with 15.4 per cent killed terminal shoots.

\section{Pines}

The results obtained from experimental planting of pines in Kettle Lakes Park are shown in Table 3.

\section{TABLE 3}

Results of Cold-Storage Planting in Spring of 1959 of Pines in Kettle Lakes Park, German TwP., Conc. 3, Lot 6

\begin{tabular}{ccccc}
\hline Species & Type & $\begin{array}{c}\text { Healthy } \\
\%\end{array}$ & $\begin{array}{c}\text { Dead } \\
\%\end{array}$ & $\begin{array}{c}\text { Missing } \\
\%\end{array}$ \\
\hline Pw & U & 81 & 17 & 2 \\
& S & 62 & 37 & 1 \\
$\operatorname{Pr}$ & $U$ & 69 & 30 & 1 \\
& S & 59 & 40 & 1 \\
$\mathrm{Pj}$ & $\mathrm{U}$ & 80 & 18 & 2 \\
& $\mathrm{~S}$ & 49 & 48 & 3 \\
\hline
\end{tabular}

Pw-white pine, $\mathrm{Pr}$-red pine, $\mathrm{Pj}$---jack pine, U-unstored, $\mathrm{S}$-stored.

One analysis of variance for numbers of dead and missing trees was made. Little difference in mortality was shown between species. All three pines, white, red, and jack, responded similarly to storage. Unstored seedlings were found to have a significantly lower mortality than stored seedlings.

\section{Discussion AND Conclusions}

On the basis of the statistical analysis and the observations made in the field it can be concluded that stored white spruce in its performance is superior to unstored spring-shipped stock from the same nursery beds.

The differences observed between white spruce stock of the two age classes were not the same in each year, but may indicate that $3 / 0$ stock reacts somewhat differently to storage than $2 / 2$ stock. This result, however, must be treated with reserve as it would be influenced by the quality of the 
planting site and by nutrient levels in the nursery beds, factors which have not been considered in these experiments.

The occurrence of severe frosts paired with good precipitation following white spruce planting in 1958 may explain the results of that year's planting, when the advanced bud development of the spring-shipped stock is taken into consideration (Table 1). The results of the 1959 planting at Fournier Township may equally well be attributed to the dormant condition of the spring-shipped stock on arrival at Cochrane (Table 1) and the relatively dry period following planting. This dry period apparently influenced the stored stock more than the spring-shipped stock and the $3 / 0$ seedlings more than the $2 / 2$ seedlings and would indicate that some desiccation had taken place during storage.

The value of the experiment with black spruce is doubtful. A 12-day delay in planting of the stored stock, which was kept in bales on the planting site, combined with the poor condition of the stock in the nursery (Table 1) may explain the generally unsatisfactory results with this species.

The experiment with pines in 1959 showed a superiority of the springshipped stock, which can be attributed to observed signs of desiccation in the stored stock, combined with the dry period following planting.

This result may indicate a difference in adaptability to storage between the pines and white spruce as has been suggested by Bjorkman (1).

In the 1959 experiment the pines were stored together with black and white spruce, but no ill effects from this association were observed on the white spruce.

Protective measures against moulding of seedlings during storage were not used and moulding did not occur, although the factor has proved important in other types of storage, Leslie (4) and Wilner and Vaartaja (6).

The implications of these experiments are evident. The presence of readily available superior seedlings at the planting site at the time when it is ready for planting is of both technical and economic advantage. The biological superiority of over-winter stored white spruce has been clearly shown in the experiments. Over-winter storage of seedlings, even when the gain in seedling performance is lacking, may have an economic merit. Transportation costs are less in the fall when roads are not restricted to half loads. Extra loading and unloading operations, during spring shipment now often made necessary by frozen and snow-covered planting sites, may be avoided when seedlings are stored in shelters located at the planting site. Fall shipping from the nursery is easier to organize than spring shipping. In the spring, nursery work often competes for labor with agriculture and other industries. Further, readily available seedling stock at the planting site will ease the difficulties in planning and conducting planting programs in northern Ontario where, because of the distance between populated areas, the establishment of special camps for the accommodation of planting crews is often a necessity.

\section{SUMMARY AND RECOMMENDATIONS}

The experimental results can be summarized as follows: 1. White spruce, $2 / 2$ and $3 / 0$ stock, can be successfully stored over winter in root cellars. 
2. Stored white spruce is resistant to damage from spring frosts and markedly superior to spring-shipped stock from the same nursery beds.

3. White spruce can be successfully stored in the same root cellar with black spruce, jack pine, red pine, and white pine.

4. It is indicated that pines suffer more from desiccation during storage than white spruce. made:

From these experimental findings, the following recommendations can be

1. Until the production of seedlings in northern Ontario can keep pace with the seedling demand, white spruce for spring planting should be fall-shipped and stored over winter in root cellars at the planting site.

2. The over-winter storage of other tree species should not be attempted on an operational basis before further experiments have been undertaken with an improved baling technique or a modified storage shelter.

\section{ACKNOWLEDGMENTS}

The authors are indebted to Professor Emeritus of Forestry T. W. Dwight for advice on experimental designs and for the calculation and interpretation of the statistical analyses. They also wish to express their gratitude to Mr. A. P. Leslie and Mr. D. H. Burton of the Ontario Department of Lands and Forests and to Dr. L. T. White of the Entomology and Pathology Branch, Department of Forestry, Ottawa, (at Forest Pathology Laboratory, Maple, Ont.) for the advice and encouragement which made these experiments possible.

\section{REFERENCES}

1. BJORKMAN, E. 1957. Om Lagring av Tall-Och Granplantor. Norrlands Skogsvaardsförbunds Tidsskrift, 465-583.

2. DAY, W. R. 1928. Frost as a cause of diseases in trees. Quart. J. Forestry, 22, 179-191.

3. JORGENSEN, E. 1958. Reforestation in northern Ontario with seedlings produced in forest tree nurseries in southern Ontario. (Mimeographed report.) Can. Dept. Agric., For. Biol. Div., Maple, Ont.

4. IESLIE, A. P. 1945. Report on the storage of planting stock over winter. Ont. Dept. Lands and Forests, Div. Res. Rept. No. 5.

5. NEGER, F. W. 1915. Rauchwirkung, Spaetfrost und Frosttrocknis und ihre Diagnostik. Tharandter Frostl. Jahrb. 66, 95-212.

6. WILNER, J. and VAARTAJA, O. 1958. Prevention of injury to tree seedlings during cellar storage. Forestry Chron. 34, 132-138. 